\title{
Finanças Públicas e Direito Tributário
}

JURANDyr COElho

\section{A}

s imprecisões dos contornos em que se situam, na atualidade, as finanças públicas se expressam, de modo particular, nas tentativas feitas de se encontrar uma definição que consiga, no seu contexto dar uma idéia válida e indiscutivel do seu conteúdo. Para a impossibilidade de se alcançar tal finalidade, concorre de um lado a afirmação - já enunciada - de que é impossivel manter as finanças públicas fundadas sôbre princípios e noções contestadas, como também, por outro lado, seria prematuro, para não dizer temerário, construir tal disciplina sôbre fórmulas ou análises de valor conceitual discutivel, enfatizando dentro dêsse ponto-de-vista uma definição soi disant indiscutivel. Na realidade, nâo há que se pretender tal objetivo dentro do dinamismo, dentro do não estaticismo, a cujas regras se submete a disciplina financeira e, por isso mesmo, relativo há de ser o valor das definições surgidas que continuarão a surgir, representando o esfôrço construtivo e laborioso daqueles que, oriundos desta ou daquela escola, sofrendo a influência desta ou daquela corrente doutrinária, procuram assentar, na medida do possivel, os possiveis têrmos exatos das finanças públicas.

Em face dessas considerações não há, portanto, por que se perquirir de uma noção geral senão quando essa noção representa na realidade a verdade - se tal têrmo assim coubesse - traduzida em têrmos de relatividade conceitual, que situaria as finanças públicas, através de fatôres influentes, de ordem a mais variada, como um conjunto de conhecimentos, de ordem complexa, onde poderiam ser equacionados receita, despesa, orçamento e crédito público. Tais problemas poderiam ensejar o estudo da transformação das técnicas usadas, dos efeitos do orçamento sôbre a economia, da ação estatal dirigida por considerações de ordem econômico-social e, de modo particular, um conjunto coordenado 
de medidas financeiras, econômicas e sociais, para u'a melhor administração das riquezas que são colocadas em mãos do Estado (Angelopoulos).

O desdobramento de campos tão diversos dá às finanças públicas uma extensão que lhe permite alcançar áreas que, em verdade, no futuro hão de se constituir autônomos, mas cujo estudo generalizado caberá perfeitamente dentro da disciplina financeira, como uma teoria geral. E, porque, enfocados dentro dêsse vasto dominio, cujos limites ainda não foram convenientemente traçados, há que se entender o caráter eclético dos estudos financeiros, atentos a todo um conjunto, de fatôres econômicos, politicos, sociais e técnico-jurídicos que repudiam a visão unilateral dos problemas ligados a finanças públicas.

Dentro dessa ordem de considerações, aquêles endereços doutrinários que visualizavam as finanças como a pesquisa das causas gerais, permanentes e necessárias dos fenômenos ligados à tributação; o estudo e a descrição dos organismos e suas ligações de caráter político-administrativo jungidas a regras de direito positivo, bem como a pretensão de ver nos fenômenos financeiros apenas um meio de assegurar uma nova repartição de riquezas dentro da comunidade, incidindo sôbre pontos específicos dos. fenômenos financeiros reforçam, na apreciação em conjunto, aquela assertiva e situam-se como elementos doutrinários de real valia dentro da disciplina, como elementos doutrinários que informam e sempre irão reforçar os argumentos dos partidários das finanças puras, das finanças jurídicas e das finanças sociais. Como que, ai se confirma a assertiva de Trotabas, na afirmação de que para se estudar as finanças públicas é indispensável, na realidade, conhecer o regime constitucional do Estado e sua organização; o direito privado, considerando os efeitos que os impostos e os. empréstimos produzem sôbre os bens submetidos àquelas normas e, como o orçamento está cada vez mais ligado à vida econômica do país, não se pode aprofundar os problemas das finanças pú blicas sem cultura econômica.

Êstes fatôres realçam as dificuldades, para uma noção exata do terreno das finanças que mesmo, quando enunciada, sòmente será válida em função da sua relatividade; no tempo, - reafirme-se - eis que a mudança dos instrumentos do Estado, a que estão ligados às finanças, há de exigir novas adaptações à medida que evolui a sociedade. Tal fato dá, na medida exata, o valor de uma definição, eis que como afirmava Pareto não existe definição rigorosamente certa, nem mesmo nas ciências matemáticas, por que o objeto do nosso conhecimento só para nossa comodidade se divide em várias partes e tal divisão é artificial e díferente com o tempo. Nesse sentido, as finanças públicas. 
hão de envolver o estudo de uma teoria geral das finanças do Estado, como aquêle conjunto de medidas que possibilitarão a administração racional das riquezas humanas e materiais, visando à prosperidade social.

Sendo conseqüentemente ligada de perto às atividades estatais, o seu processo - de criação e desenvolvimento - há que ser feito através da institucionalização dos quadros jurídicos, em que se consubstancia o seu sustentáculo necessário, pela construção dos quadros legislativos e da execução das leis. As finanças públicas se exprimem e se ativam, dentro de um quadro juridico, e a êle se submetem, dentro das realizações, que constituem o seu objetivo que, muita vez, extravasa o campo de ordem econômico-financeira.

Se as finanças públicas se colocam ao serviço do Estado, é intuitivo que o conteúdo de suas normas dependerá e será, na sua realização, o resultado das tendências políticas, de onde então o seu caráter politico-social. Como afirma Hicks, as atividades do setor público são determinadas, primàriamente, por considera ções políticas que constituem exigência para o sistema econômico, público ou privado. Isso não implica, continua êle, em afirmar que as politicas devem fundar-se em considerações, de ordem partidária; ao contrário, é absolutamente indispensável à formulação de uma política racional estabelecer, de forma sistemática e objetiva, os princípios que melhor sirvam ao aumento da riqueza e do bem-estar da comunidade. Feito isto, o assessoramento em finanças públicas deve indicar os tipos de despesas públicas e as espécies de tributos mais adequados à consecução dos fins escolhidos. Como afirma Laski, por outro lado, ao poder político cabe sempre, em última análise, decidir do volume e da prioridade das despesas. Se, dentro dêsse ponto-de-vista, focaliza-se a despesa e esta foi realçada dentro da afirmativa de Laufenburger de que as despesas públicas constituem a alma politica do Estado, não menos verdade é que o poder político impõe-se também em relação ao modus faciendi da tributação e do empréstimo. As finanças públicas, portanto, se orientam e se ajustam a êsse critério político que origina, por assim dizer, a politica financeira, eis que o Estado impóe princípios, modos de comportamento, sôbre os quais os homens devem ajustar a sua vida $e$, tais princípios emanam da vontade dos governantes e expressam, nesse particular, a vontade politica.

Identificando o problema político com o problema também de técnica financeira, como um problema de intervenção do Estado, ao considerar as finanças públicas como ciência política, entendeu Duverger que as finanças públicas não se reduziam apenas ao aspecto econômico, de regulamentação de produção e equilibrio de preços, de manutenção do poder aquisitivo da moeda, mas, 
também, como técnica financeira, podiam ser observadas no domínio social, da igualdade das rendas, no terreno familiar, na ajuda à natalidade, na subvenção às atividades artisticas ou educativas. E mais asseverava êle, que mesmo quando agiam no terreno econômico, o faziam no sentido e em função do bem-estar e do desenvolvimento da comunidade nacional, no seu conjunto.

Fatos ilustrativos, da influência política das finanças públicas, são rememorados por Hicks na afirmação de que o caminho da História está pavimentado, com a exibição de fracassos que ilustram a natureza vital das finanças públicas, fazendo referência à queda do Império Romano, à Revolução Francesa, à incapacidade germânica na guerra 1914/1918 e na Inglaterra onde, no campo das finanças públicas, foram travadas as batalhas decisivas pelas liberdades pessoais e politicas, podendo estender-se tal comentário ao próprio Brasil.

Se o fenômeno financeiro se apresenta em determinado meio politico, se êle se identifica com a vontade política, esta há de ser conduzida no sentido do interêsse geral, ou seja de prosperidade sociall.

No entanto, aí, mais uma vez, a questão se diversifica na identificação dos fins do Estado que, ao tempo das finanças clássicas, se resumia aos deveres do soberano, de manutenção da ordem interna, de respeito à soberania na ordem externa e à execução de algumas obras. Hoje, porém, já não mais se coaduna tal tarefa com aquelas que compete às funções estatais, deixando-se, desde logo, de lado, o neutralismo em matéria de finanças públicas, para torná-la atenuantes. Na verdade, o Estado, após as guerras maiores dêste século, até a presente data, chamou a si a execução de novas tarefas e que, ao início dêste século, seriam incompativeis com a concepção então dominante, entre as quais aquela de manter o emprêgo a um nivel elevado e estável. A revolução feita não trouxe, em si, a idéia de estabilização dos fins do Estado, mas antes, e, sobretudo, o de revolucionar as concepções vigentes, no sentido principalmente de proporcionar à humanidade inteira uma vida melhor e uma prosperidade sempre crescente. No dizer de Hicks, a esfera própria das atividades do Estado deve ser entendida em duas direções. Em primeiro lugar há de ser aceito como responsabilidade do Estado garantir a todos a satisfação das necessidades essenciais da vida - alimentação correta e suficiente, abrigo adequado, serviços de saúde e educação, conforme as necessidades de cada um. Tem-se como certo atualmente que o Estado deve garantir êsse minimo, através da compra e distribuição dos meios, de satisfazer as necessidades básicas, sempre que se tornar aparente que não estão sendo atendidas pela iniciativa privada. Em segundo lugar constitui iniludivel dever do Estado - tarefa que êle pode executar sòzinho - assegurar o nivel máximo de ativi- 
dade econômica e a do bem-estar social, conforme os recursos permitidos pela economia. Essas duas extensões do conceito da órbita do Estado implicam em nova e mais intima relação entre o Estado e o indivíduo, ambos na sua qualidade de produtor e consumidor; também implica em considerável extensão dos tipos de atividade pública.

Nesse particular, mais uma vez, cumpre defrontar com o problema do maior ou menor grau de participação do Estado que tem ensejado, de um lado, não só o problema da estatização, como, de idêntica forma, o daqueles que, sem chegar a tanto, permitiriam uma subdivisão de atividades em que seria admissivel a ação governamental, quando não coubesse a livre iniciativa, quando houvesse divergência entre custas e benefícios privados ou sociais ou ainda uma co-participação estatal, como modificador do padrão de consumo privado, como meio de redistribuir a renda, deixando-se, na atualidade, como atividades de caráter discutivel, problemas como energia elétrica, seguros, satélites de comunicação etc .

Da natureza de tais atividades decorre aquela de natureza social, eis que as perguntas que procuram a devida resposta dentro do terreno das finanças, tais como: a estrutura do sistema tributário ameaça a economia? Qual a melhor maneira de se enfrentar as conseqüências das depressões nos ciclos econômicos? Quais as consequiências do endividamento público? Não esgotam a matéria financeira em face do sentido social que há de se emprestar à atividade estatal.

Adolf Wagner, Constantino, Frantz, Hilferding, Moll, Goldscheid já procuraram explicar a origem dos fatos ligados àquela corrente denotando as relações que os fatos financeiros guardavam com a vida social - a carga do impôsto, a luta de classes, o domínio do Estado, as dívidas públicas - erigiram, como tema maior a existência, até mesmo, de uma sociologia financeira a quem caberia proporcionar as soluções adequadas nesse setor, tais como o papel que desempenharia a estrutura orçamentária no desenvolvimento social e, sobretudo, o problema da repartição dos encargos. Sem descurar tais doutrinas, há que se reforçar o sentido social da atividade financeira, porque ela implica na realização do bem-estar social, considerando, segundo Angelopoulos, em três itens: a) satisfação das necessidades sociais, através dos serviços públicos; $b$ ) desenvolvimento econômico do país, visando o pleno emprêgo e o crescimento da renda nacional; c) redistribuição social e econômica da renda nacional, assegurando maior produtividade à economia e à elevação do nivel de vida. Tal política - se tal têrmo assim pudesse ser utilizado - é predominante no Estado de pós-guerra.

Todavia, o instrumento essencial das finanças públicas é o orçamento do Estado e êste deve adquirir, também, um sentido 
relevante, capaz de transmitir nas suas cifras não só o seu significado de ordem financeira, não só a estruturação da vontade política, mas também há que adquirir a sua significação de ordem econômica, eis que, aí, já não mais se afigura um problema de adaptação receita-despesa, mas também de exprimir naquele documento o poderio econômico do Estado, o sentido exato da coordenação e orientação da ação do próprio Estado, permitindo-se dêste modo a intervenção direta das finanças públicas, no terreno da economia.

A influência de todos êstes elementos há que ser levada em conta na sistematização de uma teoria geral da atividade financeira do Estado, considerado do ponto-de-vista especulativo, eis que, se a relevância de tais fatôres imprimem às finanças um caráter atuante, no sentido de ser representativo de uma vontade, cujos desígnios devem ser realizados, não menos verdade é que, isso é uma de suas características atuais, pois que o modo pelo qual "o Estado" executa suas finanças, depende muito de sua politica" (Sudá de Andrade). Não obstante, tal fato ensina Laufenburger que não perdem as finanças tôda a sua autonomia. O orçamento do Estado realiza a sua missão financeira de determinação das necessidades públicas e os meios de satisfazêlas. Se as despesas constituem uma excelente maneira de intervenção econômico-social elas são limitadas pela lei imperiosa dos recursos. O impôsto não se estende indefinidamente e quando se esgota o seu caráter produtivo êle compromete o equilibrio orçamentário e, por conseqüência, o equilibrio econômico. E quanto ao crédito público, sua extensão e sua realização são funções do subscritor do empréstimo e da moeda. Qualquer que seja, porém, a conseqüência que dêsse fato se origine, o problema conceitual se fixará, sempre, no problema da atividade financeira do Estado.

Esta atividade e seu estudo no sentido puramente especulativo, em que se pesquisam os meios em que, em se completando tal procura, se coordenam medidas econômicas e financeiras visando a prosperidade social podem definir o campo de ação das finanças públicas. Tal atividade, também, pode ser considerada do ponto-de-vista positivo, em que há um conjunto de regras que tratam de aplicação normativa dos principios elaborados pelas finanças, e tais principios trazem consigo a eficácia jurídica, tão-sòmente, sem a preocupação, quer com a políticafins, quer com o problema das disponibilidades financeiras. A regulamentação, portanto, das finanças, sob o ponto-de-vista jurídico, constitui o objeto de direito financeiro, que equivale a dizer, em última análise, que sendo a atividade financeira uma atividade de caráter público há que se submeter aos critérios da ordem jurídica. 
Estudando o assunto, Blumestein já asseverava que as finanças públicas, dentro do seu restrito campo de ação, sòmente interessava de forma indireta à ciência jurídica, já que os resultados da investigação financeira servem para restabelecer a forma dessa realização, no que diz respeito à técnica tributária. A necessidade de resumir, na ordem legal, todo o procedimento no sentido de serem auferidos os meios, acarretou, dêsse modo, a submissão das finanças a determinadas regras, que se constituiram no direito financeiro. Este veio a ser, ao seu início, aquela parte do direito público que visava à regulamentação das finanças das coletividades públicas e, mais tarde, a disciplina que estuda o ordenamento das finanças do Estado e das demais entidades de direito público e as relações juridicas criadas pelo Estado e pelas referidas entidades no desempenho de atividades financeiras.

Além disso. a regulamentação das atividades financeiras, dando oportunidade a que receitas das mais variadas ordens fôssem arrecadadas, exigiu, de uma forma ou de outra, que havendo receitas do patrimônio estatal, estas, por si sós, não bastariam como anteparo ou melhor dito, como base para perfeita satisfação das necessidades. Portanto. havia que se disciplinar aquelas outras contribuições das quais se socorria o Estado, em virtude do seu poder soberano, impondo-as sôbre os demais membros da coletividade. Enraizadas tais contribuições, na ordem juridica, o conjunto de normas que a regularam passou a constituir o direito tributário. Êste apropria-se das considerações teóricas, elaboradas pelas finanças públicas, e taz incidir sôbre as mesmas, o poder e a vontade do Estado e, dessa relação, uma afirmação se estereotipa no exemplo de que, quanto maior fôr a carga tributária e, portanto, mais intensa a sua açáo econômica, mais necessária se torna a sua delimitação juridica.

Dentro dêsse ponto-de-vista não há como confundir então a atividade financeira, como objetivo precrpuo das finanças públicas, com relação à atividade de obtenção de receitas, seja para suprimento das necessidades estatais com vista à realização de determinado objetivo, estudada de modo especulativo, com a apreciação da atividade financeira, no seu aspecto positivo, onde vem tudo determinado de modo coercitivo, ensejando a incidência e atuação da norma legal. De uma lado as finanças públicas, de outro o direito financeiro e mais especificadamente o direito tributário que expõe os princípios e normas relativos à imposição e arrecadação de tributos e analisa as relações jurídicas conseqüentes, entre os entes públicos e os cidadãos, mercê de institutos e instrumentos, que dão a êste último a inegável caracteristica de direito autônomo.

Jurandyr Coelho - Auditor do Tribunal de Contas da União e Professor de Finanças Públicas. 